\title{
TOTAL QUALITY MANAGEMENT AND PERFORMANCE OF PLASTIC MANUFACTURING FIRMS IN SOUTH EAST, NIGERIA.
}

\author{
CHIEKEZIE, Obianuju Mary (Ph.D) \\ Department of Business Admininistration \\ Nnamdi Azikiwe University, Awka. \\ om.chiekezie@unizik.edu.ng \\ GERALD EMEJULU (Ph.D) \\ Department of Business Admininistration \\ Nnamdi Azikiwe University, Awka. \\ jerryemejulu@yahoo.com \\ EWANS, CHUKWUMA \\ Department of Business Admininistration \\ Nnamdi Azikiwe University, Awka. \\ chuks4real2cu@yahoo.com
}

\begin{abstract}
The need for organisational effectiveness and efficiency and the desire to gained competitive advantage in the market have made most organisations to place emphasis on continuous quality improvement. Acknowledging the need for quality improvement in meeting the demands of the changing environment therefore necessitated this study, total quality management and performance of selected plastic manufacturing firms in South East, Nigeria. The study employed correlational survey design in an attempt to identify the direction and magnitude of the relationship between studied variables. Copies of structured questionnaire were administered to the sample of two hundred and eighty five (285), out of which, two hundred and seventy (270) copies of the questionnaire were successfully returned, hence used for the analysis. Hypotheses were formulated in line with the objectives and research questions. Pearson Product Moment Correlation Coefficient Via SPSS version 20.0 was employed in testing the hypotheses. The study found a significant relationship between continuous quality improvement and market share $(\mathrm{r}=0.82)$ and significant relationship between the use of statistical process control and quantity increase per production run $(\mathrm{r}=0.84)$ of the selected plastic manufacturing firms in the South East, Nigeria. From the findings therefore, the study concluded that effective implementation of total quality management will lead to enhanced organisational performance. The study recommended that organisations should pay adequate attention to the implementation of total quality management principles. Trained personnel, who have cognate experience in the use of statistical process control to handle issues relating to their quality control problems should be employed for optimal performance. The implication of this study is that the employment of statistical process control on quality control mechanism eliminates variation in product quality and defective rate to engender products quality that meets the demands of the environment as opposed to inspection methods.
\end{abstract}

Keywords: Total Quality Management, Statistical Process Control, Continuous quality improvement, Performance, Market share. 


\section{Introduction}

The trend in business environment and the quest for operational excellence as well as the need to improve performance have made organisations to place emphasis on Total Quality Management (TQM). The concept of quality has existed for many years, though it's meaning has changed and evolved over time. In the early twentieth century, quality management meant inspecting products to ensure that they met specifications (Philips, 2004). In the 1940s, during World War II, quality became more statistical in nature. Statistical sampling techniques were used to evaluate quality, and quality control charts were used to monitor the production process. In the 1960s, with the help of so-called "quality gurus," the concept took on a broader meaning. Quality began to be viewed as something that encompassed the entire organisation, not only the production process. All functions were seen as responsible for product quality and all shared the costs of poor quality. Quality was seen as a concept that affected the entire organisation. The meaning of quality for businesses changed dramatically in the late 1970s. Before then, quality was still viewed as something that needed to be inspected and corrected. However, in the 1970s and 1980s many U.S. industries lost market share to foreign competitors (Arora, 2010).

Breth (2004) observes that the foreign competitors were producing lower-priced products with considerably higher quality. To survive, companies had to make major changes in their quality programs. Many hired consultants and instituted quality training programs for their employees. Today, successful companies understand that quality provides a competitive advantage. They put the customer first and define quality as meeting or exceeding customer expectations. Since the 1970s, competition based on quality has grown in importance and has generated tremendous interest, concern, and enthusiasm. Companies in every line of business are focusing on improving quality in order to be more competitive (Jain and Aggarwal, 2011). In many industries quality excellence has become a standard for doing business (Huge, 2007). More so, Arora (2010) observed that total quality management was necessitated by the poor quality culture and the general misconception about quality in typical traditional production setting. The objective was to get rid of poor quality from the product. Quality management has progressed, establishing proactive rather than reactive organisations. A step ahead towards quality management is TQM. Total Quality management, to Patel (1993) is a continuous effort by the management as well as employees of a particular organisation to ensure long term customer loyalty and customer satisfaction.

Plastic Products Manufacturing Firms in Nigeria dates back to the colonial administration when the British Government colonized the country (Ogunniyi, 1990). Plastic products were introduced in Nigeria as a finished product by the British colonial masters. To enhance the production of plastic products in Nigeria, the haven seeds according to Ogunniyi, (1990) were sent by Sir Henry Wickham in 1903 which were planted in the South South, Nigeria town of Sapele in the present day Delta State. This paved way for commercial rubber plantation in Nigeria which subsequently fosters the establishment of more plastic manufacturing firms in Nigeria.

Ezenwa Plastic Manufacturing Company was incorporated on the $10^{\text {th }}$ day of May, 2008. The company commenced full production on August, 2008, The company's operation site is located at 85 Amobi Street, Onitsha, Anambra State. The company produces variety of plastic products to include plastic chairs, jerrycans of different sizes, plastic buckets, paint containers, plastic spoons, plates, etc., the firm has staff strength of two hundred and eleven (211) and is structured into four departments ( Ezenwa Company Bulletin, 2016). In addition, Izuogu Plastic Manufacturing Company was incorporated on the $5^{\text {th }}$ day of September, 2004. The company commenced full production on January, 2005, The company's operation site is located at 31 Wedral Road, Owerri, Imo State. The company produces various plastic products to include plastic chairs, jerrycans of different sizes, plastic 
buckets, paint containers, plastic spoons, plates, etc., the firm has staff strength of two hundred and forty nine (249) ( Izuogu Company Bulletin, 2016).

Eastern Plastic Manufacturing Company was incorporated on the $4^{\text {th }}$ day of May, 1999. The company commenced full production on January, 2000. The company's operation site is located at Plot W Independence Layout, Emene, Enugu. The company produces variety of plastic products to include plastic chairs, jerrycans of different sizes, plastic buckets, plastic spoons, plates and many others. The firm has staff strength of two hundred and two (202) (Eastern Company Bulletin, 2016). In addition, Continental Plastic Manufacturing Company was also incorporated on the $26^{\text {th }}$ day of June, 2006. The company commenced full production on April, 2007. The company's operation site is located at 41/43 Continental plastic Road, Aba, Abia State. The company produces variety of household products that include plastic chairs, plastic spoons and plates. The firm has staff strength of three hundred and thirty two (332) (Continental Plastic Company Bulletin, 2016).

The need for operational efficiency and the desire to gained competitive advantage in the market have made most organisations to place emphasis on continuous quality improvement in an attempt to meet the demand of the environment. This is aimed at monitoring a process and eliminating causes of unsatisfactory performance at relevant stages of the quality loop in order to improve on customer needs (Arora, 2010). Yet, small scale plastic firms in the South East, Nigeria seem to be experiencing quality control problems on their products. The quality regulation and control departments appear to be ineffective as the quality control techniques are left at the mercy of the plant operators who neither have quality control operational skills on Statistical Process Control (SPC) nor acquired training on quality contrsol mechanism. This has resulted to the production of sub-standard products which apparently have failed to meet the demands of the changing business environment as customers have loss confidence on their products, and this tends to undermine the market share of these organisations.

Unfortunately the quality control technique the company uses is inspection method which is relatively reactive in measuring product quality design. It seldom prevents errors in their production process. This has resulted to wastage of materials which subsequently may have affected customer patronage on their products, which in turn, may have undermined the quantity of products produced per production run. It is therefore against this backdrop that this study is designed to determine the effect of total quality management on organisational performance.

\section{Objectives of the Study}

The general objective of the study is to evaluate the influence of total quality management on organisational performance of selected plastic manufacturing firms in South East, Nigeria. Specifically, the objectives are:

i To ascertain the extent to which continuous quality improvement relates tomarket share of the selected plastic firms in South, East, Nigeria.

ii To determine the extent the use of Statistical Process Control (SPC) relates to quantity increase per production run of the selected plastic firms in South East, Nigeria.

\section{Research Questions}

i. What is the extent of relationship between continuous quality improvementand market share of the selected plastic firms in South, East, Nigeria?

ii. To what extent does the use of Statistical Process Control (SPC) relates to quantity increase per production run of the selected plastic firms in South East, Nigeria? 


\section{Research Hypotheses}

i There is no significant positive relationship between continuous quality improvement and market share of the selected plastic firms in South, East, Nigeria.

ii The use of Statistical Process Control (SPC) has no significant positive relationship with quantity increase per production run of the selected plastic firms in South East, Nigeria.

\section{REVIEW OF RELATED LITERATURE}

\subsection{Conceptual Review}

\subsubsection{Concept of Total Quality Management (TQM)}

Quality refers to a parameter which decides the superiority or inferiority of a product or service. More and Hopkins (2000) maintain that quality is as an attribute which differentiates a product or service from its competitors. Quality plays an essential role in every business. Business organisations need to emphasize on quality of their brands over quantity to survive the cut throat competition (More and Hopkins, 2000). Patel (1993) asserts that TQM is a continuous effort by the management as well as employees of a particular organisation to ensure long term customer loyalty and customer satisfaction. Powell (2000) sees Total Quality Management (TQM) as management approach to long-term success through customer satisfaction. In a TQM effort, all members of an organisation participate in improving processes, products, services, and the culture in which they work.

In addition, Oakland, (2002) sees total quality management as a management system for a customer focused organisation that involves all employees in continual improvement of all aspects of the organisation. TQM uses strategy, data, and effective communication to integrate the quality principles into the culture and activities of the organisation (Huge, 2007). Remember, one happy and satisfied customer brings ten new customers along with him, whereas one disappointed individual will spread bad negative image to your potential customers (Morgan and Tunic, 2010). TQM is an indispensable total that defines organizational approach for meeting customer needs and expectations that involve all managers and employees in using quantitative methods to improve continuously the organizat ion's processes, products quality and services ( More and Hopkins 2000). TQM is a business philosophy that embodies the belief that management process must focus on integrating the idea of customer-driven quality through an organisation (Aluko et al, 2004). In the view of these scholars, it means that all organisational activities initiated by the management should be targeted at satisfying customers with high quality products and services. This is to ensure the attainment of competitive edge in the market place.

Eze (2002) opines that TQM is seem as people focused management system that aims at continual increase in customer satisfaction of organisational resources to improve the effectiveness, efficiency, flexibility and competitiveness of business as a whole. TQM according to Eze (2002) consist the entire organisation getting organised in every department, with every single person at all levels. This involves, putting in place process and system which will ensure that every aspect of its activity is aligned to satisfying customer needs and the organisation's objectives without waste of efforts by releasing the full potential of every person in the organisation.

\subsection{Theoretical framework}

The underpinning theory of this study is anchored on Deming Wheel Theory propounded by Deming (1950). This theory believes that TQM creates organisation system that enhance corporation and learning, the implementation of process management practices, that leads to continuous improvement of processes, products etc., that meet customers' satisfaction. 
Deming (1950) advocates the move of quality away from being a purely operations activity into a major concern for whole organisation. The theory laid emphasis on the important role of the top management commitment in changing processes and systems. Deming (1950) argues that top management is responsible for most quality problems, simply because it is their duty to create and disseminate a vision to move the firm towards continuous quality improvement, especially given the dynamism of business environment. The following are the 14 points principle of TQM.

1) Create consistency of purpose for improvement of product and service.

2) Adopt the new philosophy, we are in a new economic age, customer should have a reliable product in the first place.

3) Do not depend on inspection as a way to achieve quality. Improve processes.

4) End the practice of awarding business on the price tag alone. Single source, long-term relationships with supplier have advantage of consistency and reduced cost.

5) Constantly improve production and service system, you must develop process that lead you to improve everything.

6) Institute training on the job.

7) Institute improved supervision and leadership.

8) Drive out fear.

9) Break down barriers between departments and locations.

10 Eliminate targets asking for increased productivity without providing methods.

11 Eliminates numerical quotas.

12 Remove barriers between the worker and the right to pride of workmanship so also with all staff.

13 Institute education and retraining programmes.

14 Put everybody in the company to work to accomplish the transformation. Changes take time.

The aforementioned principles by Deming (1950), if effectively implemented, should create enabling environment for organisations to achieve satisfactory level of product quality. The theory assumes that the initial investment in quality will be justified in the long-run as a result of total reduction in quality cost. The relevance of this theory on the present study is the fact that it laid emphasis on the imperativeness of continuous quality improvement as a prerequisite in meeting the demands of the environment. The theory overtly affirmed that customer satisfaction is the focal point of total quality management. Therefore, when a customer is satisfied with company's product quality, he/she will inform others, as such, continuous quality improvement results to increased customer patronage on organisational products, which in turn, increases their market share.

\subsection{Empirical Review}

Jackson (2000) carried out a study on effects of total quality management on organisational performance in Algeria. The objective of the study was to explore the implications of total quality management on organisational performance of selected manufacturing firms in Algeria. The study employed a descriptive design, of which structured questionnaire were administered to the sample of Two hundred and thirty four (234) drawn from the population of the study. The data collected from the respondents were analyzed with percentages and Chi-square $\left(\mathrm{X}^{2}\right)$. The findings revealed that total quality management creates a sustainable framework that drive high performing organizations, especially giving the dynamism of business environment, and concludes that organisations should consciously improve their processes by adhering strictly to the principles of TQM for improved performance in their operations. The study recommended that organisations should pay a concerted attention to 
issues that necessitate continuous quality improvement in order to meet the demands of the environment.

Stoner (2004) studied implications of total quality management on performance in USA. The study was designed to evaluate the implications of total quality management on performance of the selected manufacturing firms in USA. The study employed a survey research design, of which structured questionnaire were administered to the sample of three hundred and fifty (350) drawn from the population of the study. The data collected from the respondents were analyzed with one way ANOVA. The findings revealed that total quality management has a significant impact on competitive performance for the organisations. There were minor differences in quality management practices across the countries in terms of support of top management for quality, involving customers in production and design process, involving suppliers in quality improvement, and participation of employees in small, group activities. The similarities in quality management practices across the countries exist in activities related to process management and training for employees, in terms of competitive performance were significantly affected by quality management practices. The study recommended customer involvement, support from the top management, cleanliness and process control for improving competitive performance.

Huge (2001), studied quality control on performance in manufacturing industries in Malaysia. The objective of the study was to present the implementation of quality control in four manufacturing firms. The study employed descriptive research design of which structured questionnaire was administered to the sample of the study. The data collected were analyzed with Pearson Correlation Coefficient. The result shows that top management was the driver for quality management implementation. The study also revealed that employees training and involvement are significantly correlated with internal quality results. The study recommended that for business to perform better in both external and internal quality results, management must take the lead and backup their ideas through proper training and involvement of employee in quality issues in the organisation.

\subsection{Summary of Reviewed Literature}

In the light of the reviewed literature, total quality management spawns from organisations predispose desire for operational excellence in securing competitive advantage giving the dynamism of business environment. Total quality management was measured across two dimensional construct of quality management, which includes continuous quality improvement and Statistical Process Control (SPC) and performance were also measured with market share and quantity increase per production run. Each of the two measures of either total quality management or performance has its associated antecedents and outcome.

However, most of the studies reviewed, treated total quality management as a single construct that measures performance in organisations. None of the studies integrated continuous quality improvement and statistical process control to measure total quality management and seldom determine its effect on performance. Therefore, it was apparently difficult to ascertain the net effect(s) of the interactions of continuous quality improvement on market share and the use of statistical process control on quantity increase per production run without research-based evidence. This present study is designed to fulfill these gaps.

\section{Methodology}

The study was a survey-type of research that employed a correlational research design in an attempt to identify the direction and the magnitude of the relationship between variables under study. Structured questionnaire drawn on 5 point scale rating was administered to a sample of two hundred and eighty five (285) respondents drawn from the population of nine hundred and ninety four (994), out of which, 270 copies were successfully returned, hence, 
used for the analysis. However, to test the dimensional structure, usability and suitability of the research instrument, component factor analysis involving the use of varimax rotation was employed. Also, for sampling adequacy Bartlett Test of Sphericity and Kaiser-Meyer-Olkin were employed. Cronbach alpha coefficient was used to determine the reliability of the research instrument. The reliability results were 0.87 and 0.71 for continuous quality improvement on market share and quality design on quantity increase per production run of the selected plastic firms in the South East, Nigeria, suggesting that the data instruments were reliable. The formulated hypotheses were tested using Pearson Product Moment Correlation Coefficient Via SPSS version 20.0.

Table 3.1: Component Factor Analysis

\begin{tabular}{|c|c|c|c|}
\hline $\begin{array}{l}\text { Component extractions and items } \\
\text { Factor One: Continuous } \\
\text { improvement and Market share }\end{array}$ & $\begin{array}{l}\text { Factor } \\
\text { Loadings }\end{array}$ & $\begin{array}{l}\text { Mean } \\
\text { Scores }\end{array}$ & $\begin{array}{l}\text { Cronbach's } \alpha \\
\text { if } \\
\text { item deleted }\end{array}$ \\
\hline $\begin{array}{l}\text { Improving the quality of the products enables } \\
\text { us to meet the demands of the environment. }\end{array}$ & 0.655 & 4.0952 & .872 \\
\hline $\begin{array}{l}\text { Quality improvement sustains customer } \\
\text { patronage on our products. }\end{array}$ & 0.826 & 3.8971 & .763 \\
\hline $\begin{array}{l}\text { Quality improvement helps the firm to secure } \\
\text { competitive edge. }\end{array}$ & 0.904 & 4.1432 & .786 \\
\hline $\begin{array}{l}\text { Increased market share is a function of quality } \\
\text { improvement. }\end{array}$ & 0.687 & 3.3241 & .742 \\
\hline Market share of every firm is increase when & 0.876 & 3.8765 & \\
\hline
\end{tabular}
products quality meets customer specifications.

Reliability result $=0.89$, eigenvalue $=70.659, \%$ variance $=27.801$ and Mean score $=4.0256$.

\section{Factor Two: Statistical Process Control and Quantity increase per run}

SPC uses control charts to reduce variation in product quality.

The use of SPC technique eliminates wastage in production.

Productivity is enhanced with the application of

SPC in operations management.

Quantity increase is achieved per production run via $\mathrm{SPC}$

SPC easily detects system effect

0.767

3.784

.823

0.785

4.891

.817

0.814

3.563

.701

0.802

3.897

.707

0.793

3.887

.776

Reliability result $=0.84$, eigenvalue $=71.659, \%$ variance $=17.801$ and Mean score $=4.7256$.

Table 3.1 above shows the component factor analysis of the instrument involving the use of varimax rotation for the study. A pilot study was employed in an attempt to ascertain the internal reliability of the instrument. The employment of component factor analysis was appropriate in exploring sampling adequacy, which was shown by the Bartlett Test of Sphericity $\left(\chi^{2}=562.632, \mathrm{p}<0.000\right)$ and the Kaiser-Meyer-Olkin measure of sampling adequacy was greater than $0.01(\mathrm{KMO}=0.751)$, which show that use of factor analysis was appropriate. Further inspection of the correlation matrix for the factorability of $\mathrm{R}$ indicated 
that many coefficients were above 0.30 , another strong evidence for the suitability of factor analysis. The resultant factor structure explained 4.0256 per cent of the variance with eigenvalues greater than 0.01 . More so, there was considerably evidence of high communalities subsisting across each scale components. In addition, the Cronbach's alpha $(\alpha)$ for each instrument was respectively calculated to establish the constructs of the component extractions were internally consistent. Table 1 also shows the Cronbach's alpha $(\alpha)$ result on five instruments loaded to measure continuous quality improvement on market share of the small scale plastic manufacturing firms in the South East, Nigeria. The result of the Cronbach's alpha $(\alpha)$ v salues of the five instruments ranged from .789 to .872 , respectively. Therefore, $\alpha$ coefficient of the total was 0.89 , which is absolutely considered good indicators of reliability of the instrument.

Factor I shows 17.80 percent variation in the five items loaded for continuous quality improvement on market share, with the overall mean score of 4.0256. The mean scores of all the constructs were above .30. This implies that each of the measuring instruments has propulsive effect on small scale business performance. Market share was used as a construct measure of business performance of plastic manufacturing firms in the South East, Nigeria. Therefore, continuous quality improvement enable plastic manufacturing firms to come up with product quality that meets customer's specification in the changing environment.

Factor 2 above shows 17.801 percent variation in the five items loaded for Statistical Process Control (SPC) and quantity increase per production run of the plastic manufacturing firms in the South East, Nigeria. The overall mean score of the five items is 4.7256 and the mean scores of all the constructs were also above .30. This means that the five measuring instruments were respectively significant in measuring Statistical Process Control (SPC) and quantity increase per production run. The result of the Cronbach's alpha $(\alpha)$ values of the five instruments ranged from .823 to .776 , respectively. Therefore, $\alpha$ coefficient of the total was 0.89 , which is absolutely considered good indicators of reliability of the instrument.

\section{Hypotheses testing}

Results

Hypotheses 1: There is no significant positive relationship between continuous quality improvement and market share of the selected plastic firms in South, East, Nigeria.

\begin{tabular}{|ll|r|r|}
\hline & \multicolumn{1}{c|}{$\begin{array}{c}\text { Continuous } \\
\text { Quality } \\
\text { Improvement }\end{array}$} & Market Share \\
\hline Continuous Quality & Pearson Correlation & 1 & $.824^{* *}$ \\
Improvement & Sig. (2-tailed) & 270 & .000 \\
& $\mathrm{~N}$ & .824 & 270 \\
Market Share & Pearson Correlation & .000 & 1 \\
& Sig. (2-tailed) & 270 & 270 \\
\hline
\end{tabular}

**. Correlation is significant at the 0.01 level (2-tailed). 
Hypotheses 2: The use of Statistical Process Control (SPC) has no significant positive relationship with quantity increase per production run of the selected plastic firms in South East, Nigeria.

\begin{tabular}{|c|c|c|c|}
\hline & & $\overline{\text { SPC }}$ & $\begin{array}{l}\text { Quantity Increase } \\
\text { per production run }\end{array}$ \\
\hline \multirow{3}{*}{ SPC } & $\begin{array}{l}\text { Pearson } \\
\text { Correlation }\end{array}$ & 1 & $.840^{* *}$ \\
\hline & Sig. (2-tailed) & & .000 \\
\hline & $\mathrm{N}$ & 270 & 270 \\
\hline \multirow{3}{*}{$\begin{array}{l}\text { Quantity Increase per } \\
\text { production run }\end{array}$} & $\begin{array}{l}\text { Pearson } \\
\text { Correlation }\end{array}$ & $.840^{* *}$ & 1 \\
\hline & Sig. (2-tailed) & .000 & \\
\hline & $\mathrm{N}$ & 270 & 270 \\
\hline
\end{tabular}

\section{Discussion of Findings}

The correlation result in Table 2 shows that there is a significant positive relationship $(\mathrm{p}=0.000)$ between continuous quality improvement and market share of the selected plastic manufacturing firms in the South East, Nigeria. This was shown by a strong correlation coefficient ( $\mathrm{r}$ ) of (0.82). The implication of the result is that continuous improvement of the quality of their products will result to increase customer patronage of the selected plastic manufacturing firms in the South East, Nigeria. Since the P-value is less than 0.01, there exists enough evidence to reject the null hypothesis and conclude that there is a significant positive relationship between continued quality improvement and market share in the selected plastic firms in South East, Nigeria.

More so, the correlation result in Table 3 also shows a significant relationship $(\mathrm{p}=0.000)$ between Statistical Process Control (SPC) and quantity increase per production run of the selected plastic manufacturing firms in the South East, Nigeria. This was shown by a strong correlation coefficient (r) of (0.84). This imply that appropriate quality design on their products will culminates to quantity increase per production run of the selected plastic manufacturing firms in the South East, Nigeria. Therefore, increase in the sale of their products, will in turn, result in quantity increase per production run, which is a good construct for performance measure. Since the P-value is less than 0.01, there exists enough evidence to reject the null hypothesis and conclude that there is a significant positive relationship between statistical Process control (SPC) and quantity increase per production run in the selected plastic firms in South East, Nigeria.

\section{Conclusion}

From the findings of this study, the study concludes that there is a strong positive correlation between Total Quality management (TQM) and organisational performance. The implication of this strong correlation is that effective implementation of total quality management will significantly enhance organisational performance, vice versa. The study provided empirical evidence of continuous quality improvement and Statistical Process Control (SPC) as decomposed variables of total quality management that predict organisational performance. The correlation results point to the fact that organisations, especially manufacturing firms in the South East, Nigeria to pay a concerted attention on Total Quality Management (TQM), as an important policy variable necessary for enhancing organisational performance, especially giving the dynamism of business environment. Top management plays a critical role in 
implementing effective total quality management because they initiate the idea, while others follow suit.

\section{Recommendations}

Based on the above conclusion, the study made the following recommendations:

(i) The management of these plastic firms should pay adequate attention to the implementation of companywide and customer centered TQM programmes to achieve and sustain customer satisfaction and patronage. Effective implementation of Total Quality Management (TQM) has the potentials of sustaining the life of organisations in the face of stiff competition in meeting their desired performance.

(ii) Management of plastic firms should take effective measures in ensuring effective monitoring and sustainability of their product design to forestall customer's complaint, and loss of confidence on their products, which may have a propulsive affect on their performance.

(iii) The management of these organisations should continue to improve on their quality control mechanisms to ensure conformity to specifications or standards in meeting the demands of the changing business environment.

(iv) They should employ the services of trained and experience personnel on quality control mechanisms that can effectively use Statistical Process Control to handle issues relating to quality control problems for effective and efficient performance.

\section{References}

1. Aluko M/, Odugbesan O, Gbadamosi G., \& Osuagwu L. (2004). Business Policy and Strategy.Lagos: Longman Publicaations.

2. Arora, K.C. (2010), Total Quality Management. New Delhi: Kataria and Sons Limited.

3. Beth, M.J., (2004), Total Quality Management. Kenya: Jonkee Publications.

4. Continental Plastic Company Bulletin (2016), Home of Plastics. Aba: James Publucaltions

5. Deming, W.E. (1950): out of the crisis Cambridge, McGraw-Hill: Home-wood LLinois Publications.

6. Eastern Company Bulletin (2016), Meeting the Demands of the Changing Environment. Enugu: Eastern publications.

7. Ezenwa Company Bulletin (2016), Leading Name in House-hold Products.Onitsha: Odumegwu Publications.

8. Ezeh,J.A and Onodugo, V.A. (2002). "Business Policy and Strategic Management, Issues and Trends, 2nd Edition, Enugu: Knismann Publishers Limited.

9. Huge, B. (2007), Total Quality Management in organizations, Malaysia: Myles Publications.

10. Huge, B. (2001), Effect of quality control on performance of Manufacturing Firms in Malaysia. Journal of Business Management Sciences Vol 4. No. 2, Pp128-130..

11. Izuogwu Company Bulletin (2016), Achieving Competitive Edge in the Changing Environment. Izogwu Limited.

12. Jackson, K (2000) Effects of Total Quality Management on Organizational Performance. Journal of Business Studies Vol 3. No. 2, Pp 122-128.

13. Jain and Aggarwal (2011), Production Planning Control and Industrial Management. New Delhi: Khanna Publishers.

14. More, V.F, and Hopkin, M.N. (2000), The relationship between Total Quality Management (TQM) Practices and their Effects on Firm Performance. Journal of Operations Management, Vol. 21. No. 4. Pp 405-435. 
15. Morgan, E. and Tunic, K.L. (2010), Total Quality Management Practices. 3rd Edition, New York: Eaglewood Press.

16. Oakland, M.T. (2002), Implications of Total Quality Management on Organizational Performance. Journal of Quality Management. Vol.1. No.1 Pp 91-108

17. Ogunniyi, A. (1990). ISO 9000 Series of Standards: Keys to Standards Measurement on Products Quality. Lagos: Adeyemi Publications.

18. Philips, K.L. (2004), Total Quality Management. New-Delhi: Berghahn Press.

19. Powell T.C. (2000) TQM as Quantitative advantage: A review and empirical study.Journal of Strategic Management, Vol.16 (1), pp.15-37

20. Patel, F.D. (1993) A Journey Towards TQM through ISO 9000 certification-A Singapore Experience. Journal of organizational Behaviour,Vol. 9,(5) pp.364-371.

21. Stoner, V.N. (2004), Implications of Total Quality Management (TQM) on Performance. Journal of Business Studies, 4(7)231-240. 